\title{
The Sources of Water Supply, Sanitation Facilities and Hygiene Practices in an Island Community: Amassoma, Bayelsa State, Nigeria
}

\author{
Raimi Morufu Olalekan1,3*, Abdulraheem Aishat Funmilayo², \\ Major Iteimowei², Oluwaseun E Odipe ${ }^{3}$, Isa Hussain Muhammad³, \\ Onyeche Chinwendu ${ }^{4}$ \\ ${ }^{1}$ Department of Community Medicine, Niger Delta University, Nigeria \\ ${ }^{2}$ Department of Sociology, Niger Delta University, Nigeria \\ ${ }^{3}$ Department of Environmental Health Sciences, Kwara State University, Nigeria \\ ${ }^{4}$ Department of Sociology, Ignatius Ajuru University of Education, Nigeria
}

*Corresponding author: Morufu Raimi, Department of Community Medicine, Niger Delta University, Bayelsa State, Nigeria, Email: ola07038053786@gmail.com

\section{Abstract}

Background: The polarization of the Nigerian society with a population of about 198 million people, growing at the rate of 3.2\% per annum, into a large rural sector and a small urban component provides a basis for the inadequate provision of health infrastructure in the rural areas. For instance, over $65 \%$ of Nigerian population who live in the rural areas are most neglected and deprived of basic services as well as other modern infrastructural necessities that are essential to the maintenance and promotion of good health. Hence its supply is a major factor for consideration in the health of any community. This study aimed to assess the sources of water supply, sanitation facilities and hygiene practices in an island community of Amassoma, Bayelsa State.

Materials and Method: A cross sectional descriptive study design was used, the 357-sample size for housing units was determined using the appropriate statistical formula and systematic sampling method was used with a sampling interval of two. A 30-item administered closed-ended structured questionnaire was used. Data was collected from 198 households and analysed using descriptive statistics with frequency counts and simple percentages using computer aided statistical analysis by Microsoft Excel.

Results: The result identified multiple sources of water supply which includes rain, river/stream, pipe borne, borehole, sachet water and table water with borehole and sachet water being the major source. The sanitary condition of the water source shows that $28.8 \%$ dirty, $5.6 \%$ fairly clean, $68.7 \%$ admitted to not treating their water at home, while $15.2 \%$ just store at home, $10.1 \%$ use water guard and $6.0 \%$ practice boiling. For the toilet facilities, $40.9 \%$ use septic tank, $33.8 \%$ do open defecation, $15.7 \%$ use the river, $13.1 \%$ use traditional pit latrines, while $9.0 \%$ use ventilated improved toilet pit latrine. $5.6 \%$ were fairly clean, $28.8 \%$ dirty while $39.4 \%$ use the river for bathing purposes, $14.1 \%$ have open bathrooms 
while $1.6 \%$ have other forms of bathroom facilities. $63.6 \%$ dump their refuses at open dump sites while $10.6 \%$ burn theirs. 9.9\% dump refuses in the river while $22.2 \%$ practice other forms of refuse disposal. Hand washing, an important hygiene practice with $95.9 \%$ practicing hand washing after visiting the toilet, $76.8 \%$ before cooking, $72.7 \%$ after cooking while $85.9 \%$ before eating. Common health problems show, $25.3 \%$ of the respondents had malaria, $20.7 \%$ diarrhoea, $9.1 \%$ skin rash, while $2.0 \%$ had cough. About $31.8 \%$ of them attributed poor sanitation as a causal factor, $23.2 \%$ of the respondents associated water as a possible causal factor, while $44.9 \%$ did not attribute their health challenges to any causal factor. $52.0 \%$ purchase drugs from patent drug stores for treatment, $36.9 \%$ visit hospitals, while $11.1 \%$ patronize traditional doctors.

Conclusion: Sanitation facilities and safe water supply are insufficient in Amassoma community. This along with hygienic practices led to the prevalence of common illnesses in the community. Poor sanitation and unhygienic practices are still widely practiced. The State and Local Government should provide adequate portable water and sanitation facilities in public places with emphasis on citizen advocacy in the area of health education campaign.

Keywords: Community Stakeholders; Partnerships; Sustainable Development; Coordinated; Engagement; Environmental Management; WASH Policy

\section{Introduction}

Adequate sanitation, together with sound hygiene and safe water, are fundamental to good health and to social and economic development. Improvements in one or more of these three components of good health can substantially reduce the rates of morbidity and the severity of various diseases and improve the quality of life of huge numbers of people, particularly children, in developing countries [1,2]. Although linked, and often mutually supporting, these three components have different public health characteristics. Interestingly, water is essential to sustain the lives of human beings. Springs and stream waters are the main sources of drinking water in remote areas [3]. The drinking water source should meet the tolerable water quality levels [4]. The water users in remote areas face high risks of a health problem when their water source does not meet satisfactory water quality levels [5]. In addition, unsafe excreta disposal is still widely practiced despite the presence of oil companies in the Central Senatorial District. Critical hand washing practice was still poor amongst residents [6]. Interestingly, water quality is dependent on physicochemical parameters which in turn can be affected by geology, climate, agriculture, mining, and industry. Hence, rural people lack other basic infrastructural necessities like Potable water that are essential to the maintenance and promotion of good health [7-9]. The outcome of these inadequacies is that the rural dwellers are subjected to high incidence of morbidity and mortality resulting from the prevalence of preventable diseases [10]. the accessibility of water, sanitation and hygiene in our home and schools are vital as it affects a child's potential for growth which can also be affected by water and sanitation related diseases; such as diarrhoea, dysentery, cholera, guinea worm etc. especially children between ages 5 and 14, with around 45,000 under five deaths recorded in Nigeria each year due to diarrhoea attributed to unsafe water and poor sanitation $[4,5]$. These tend to have deleterious effect on growth, physical activities, performances, cognition and concentration in school $[8,9]$.

The Millennium Development Goals (MDGs) target 7C was to "halve, by 2015, the proportion of the population without sustainable access to safe drinking water and basic sanitation"; of which there was an increase by 2.6 billion people who gained access to improved drinking water sources between 1990 and 2015, with the world meeting the target of reducing by half, the number of people without access to improved sources of water five years ahead of plan. Similarly, 2.1 billion people gained access to improved sanitation globally. Despite the progress made, as much as 2.4 billion still use inadequate sanitation facilities which include the 946 million people practicing open defecation. Nigeria has met this target of improved drinking water sources but failed to meet the target on basic sanitation as indicated in the sub-Saharan (regional) report. Good hygiene practice and the effectiveness of hygiene promotion in an environment or 
society are severely limited where water supply and sanitation facilities are inadequate or non-existent. Therefore, the right use and maintenance of water and sanitation facilities can be achieved by sustaining hygiene promotion, where water and sanitation facilities are tools for improved hygiene behaviours or practices. It is known that water covers $71 \%$ of the Earth's surface and is vital for all known forms of life. About $96.5 \%$ of the planet's water is found in oceans, $1.7 \%$ in ground water, $1.7 \%$ in glaciers and the ice caps of Antarctica and Greenland, a small fraction in other large water bodies and $0.001 \%$ in the air as vapor, clouds and precipitation. The role of water in carrying out standard sanitary and hygiene practices cannot be over emphasized; hence a good knowledge of its source(s) will be of great benefit improving sanitation and hygiene practices.

The public health challenges of Amassoma community, as of today, where this study was focused remind us of the changing concepts of public health and the confused concepts of preventive health care of the yester years. The problems of water shortage amidst plenty of rainfall, shallow ground waters often polluted, rich ecosystems and biodiversity and natural resources do not match with the developmental activities, hunger, poverty and insanitary environment and preventable disease burden. Water is a resource that is essential for life, without water there is no life. It determines the overall socio-economic development of any nation. Most times rural areas are more deficient in the availability of safe water, which leads to poor hygiene practices and affects sanitation negatively, Amassoma community is not an exception. So therefore, the objective of this study is to assess the different sources of water supply and their adequacy in Amassoma community, assess the sanitation facilities, their adequacy and the awareness in the community, assess the level of hygiene practices in the community and identify the gaps and make recommendations on how to sustain effectively the water supply, sanitation and hygiene practices.

\section{Research Methods}

\section{Description of the Study Area}

The study was carried out in Amassoma, a rural community and host Niger Delta University, located in Southern Ijaw Local Government Area of Bayelsa State, South-South Nigeria. It is one of the communities in Ogboin Clan with a population of about 6,970 people [11]. Amassoma is located on latitude 4.97030 (458'13.008') N and longitude $6.10970\left(66^{\prime} 34.992^{\prime \prime}\right) \mathrm{E}$, with an altitude of $79 \mathrm{~m}$. It is politically divided into three wards. It is easily accessible by road and water and her indigenes are very hospitable. Amassoma has two major road interlinked with several streets and walk paths. Along the streets are compounds made up of households. The language spoken here is Ijaw. However, like the rest of Nigeria, English is the official language. The local population engages in fishing and farming on a subsistence and commercial level (Figure 1).

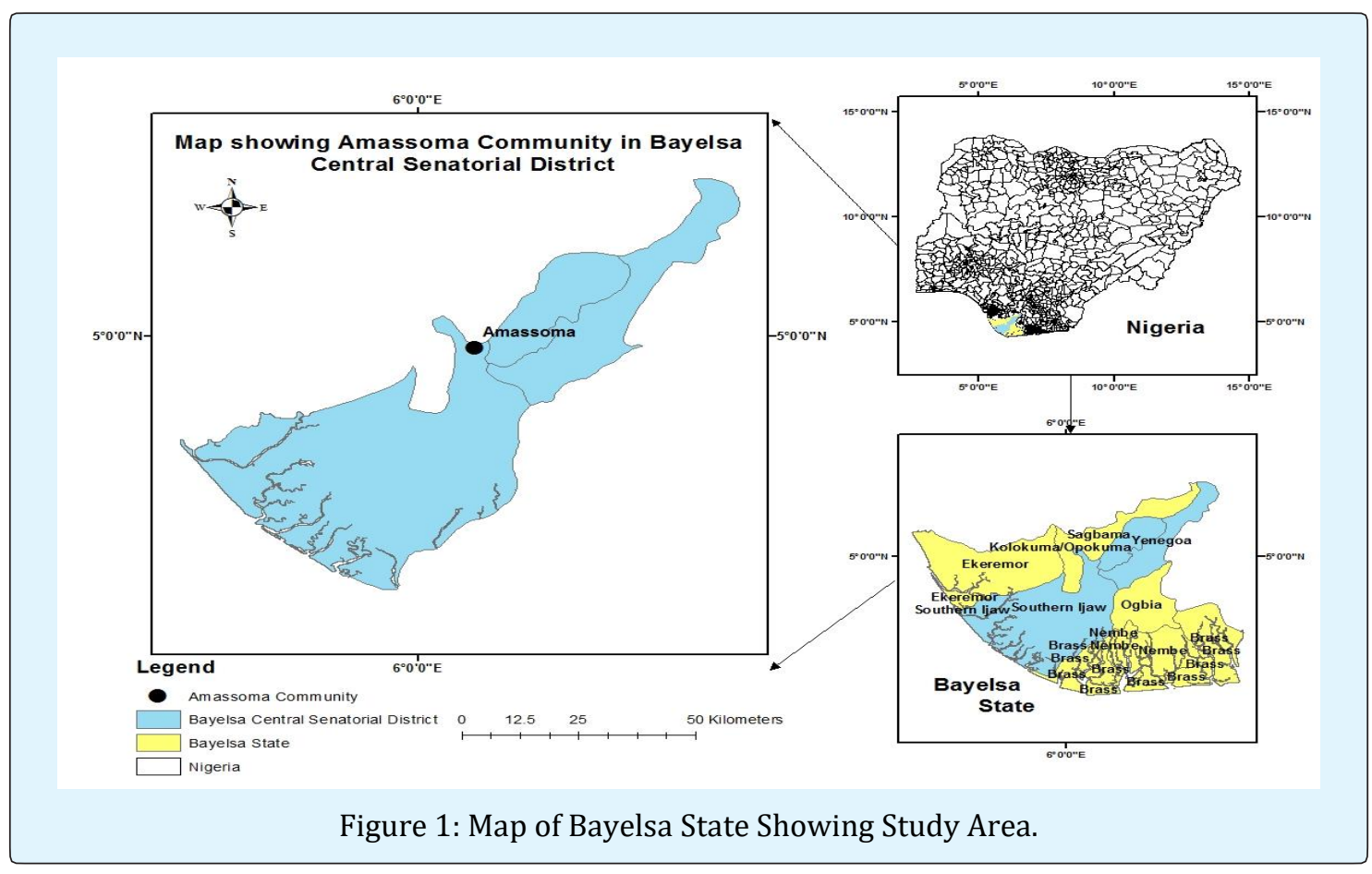

Raimi Morufu Olalekan, et al. The Sources of Water Supply, Sanitation Facilities and Hygiene Practices 


\section{Study Design}

The study is descriptive cross sectional in nature and addresses the sources of safe water supply, sanitation facilities and hygiene practices in Amassoma community of Southern Ijaw of Bayelsa State.

\section{Study Population}

Population census for this monolithic town was above 11,000 in 1953 and rose to about 17,246 in 1963 and the current figure of Amassoma is expected to exceed 50,000 due to massive influx of students, staff of the University and visitors. It has a land-mass of about $4 \mathrm{~km}^{2}$. The town has about 2,100 households and of which study population is made up of families that reside in Amassoma, which comprise of men, women and children, all of different age groups. There are about 357 houses in the sampled area in which these individuals reside. The average family size in Amassoma Community is 7 per household.

\section{Sample Size Determination}

Sample size was calculated using the appropriate statistical formula for sample size:

$$
\mathrm{n}=\frac{\mathrm{X}^{2} \mathrm{NP}(1-\mathrm{P})}{\mathrm{ME}^{2}(\mathrm{~N}-1)+\mathrm{X}^{2} \mathrm{P}(1-\mathrm{P})}
$$

$\mathrm{X}=95 \%$ Confidence Interval level $=1.96$

$\mathrm{N}=$ number of households in Amassoma community = 357

$\mathrm{P}=0.64$

$\mathrm{ME}=0.05$

Using the above formula, it was equal to 178

Attrition $=10 \%$ of $178=17.8$

Total sample size $=196$

However, a sample size of 198 was used. This was done to eliminate any errors.

\section{Sampling Method}

Systematic sampling method was used as follows;

1 . The housing units were numbered in sequence using block letters which followed this pattern: State/LGA/Ward/House number. e.g. BYS/SILGA/02/001.

2. The sampling interval was determined by the formula $\mathrm{K}=\mathrm{N} / \mathrm{n}$.

Where $\mathrm{N}=$ total housing units

$\mathrm{n}=$ sample size

$$
\mathrm{K}=\frac{357}{198}
$$

$\mathrm{K}=2$
3. Selection of houses was by systematic random sampling. The first housing unit was selected by balloting between the sampling intervals 1-3.

4. Thereafter the sampling interval of two was used, that is, every Kth housing unit.

\section{Data Collection}

Method of data collection was by interviewer administered questionnaires. The interviewer administered questionnaires were administered to participants regardless of their educational level. The questionnaires consisted of five sections namely; Section A: socio-demographic data, Section B: knowledge of water sources, Section C: sanitation practices, Section D: hygiene practices and Section E: Perceived impact on health. There were Key Informant interviews and verification of the facilities using a check list.

\section{Data Processing}

Data obtained from questionnaires were analyzed using computer aided statistical analysis by Microsoft Excel. Data was presented in form of tables, charts, means and percentages.

\section{Results}

\section{Demographic Profile of Respondents}

Table 1 shows the socio-demographic data of 198 respondents in frequencies and simple percentages. Of the 198, 103(52.0\%) are females and 95(48.0\%) are males. Among the age brackets, $80(40.0 \%)$ are within the ages of 18 - 29years, 71(36.0\%) are within $30-39$ years, $34(17.0 \%)$ are within the range of $40-49 y e a r s$, while $13(7.0 \%)$ are within the age of 50 - 59years. However, it can be seen that majority (76\%) of the respondents are young people and are either students or staff of Niger Delta University.

In the respondents' level of education, the highest in the sample survey is the secondary school leavers (secondary level) with 102(51.5\%) followed by those who possess higher degree of any form, either B.Sc., B.Ed., M.Sc. etc. (tertiary level). The high number of higher degree holders $52(26.3 \%)$ in the sample could be as a result of the university sited in the study area, followed by primary level of education $29(14.6 \%)$, while $15(7.6 \%)$ are not educated.

Regarding the respondents' occupation, trading (which covers any kind of legal business ranging from photocopying to selling of other items) and civil servants were the highest at $68(34.3 \%)$ and $55(28 \%)$ respectively. 
The high percentage of the two occupations is because of the establishment of NDU in the study area. Commercial driver $40(20.7 \%)$, is the third highest and this is becoming a predominant occupation for the youth due to the establishment of the university in the community, followed by farming $31(15 \%)$ and fishing $4(2 \%)$ which was the predominant occupation of the people before the establishment of the university in the community is now gradually disappearing.

In terms of family size, the category of family size 1-5 (50\%) and 6-10 (36\%) represents the highest group; have a family size of $6-10,6(3.0 \%)$ have a family size of 11 $15,1(1.0 \%)$ has a family of 38 people while the family size of 22 respondents could not be determined.

In terms of duration of residence, 125(63.0\%) of the respondents had lived in Amassoma Community for a maximum of 10 years, $19(10.0 \%)$ had lived in Amassoma between 11 - 20 years, 7(4.0\%) between 21 - 30years, $3(2.0 \%)$ between 31 - 40years, while the duration of stay of about $44(22 \%)$ respondents could not be ascertained.

As regards ownership of the house, 102(52.0\%) of the houses are owned by respondents while $96(48.0 \%)$ of respondents are living in rented apartments and they could either be students or non-natives residing in the community because of their business.

\begin{tabular}{|c|c|c|}
\hline $\begin{array}{l}\text { Demographic } \\
\text { Information }\end{array}$ & Frequency = 198 & Percentage (\%) \\
\hline \multicolumn{3}{|c|}{ Age } \\
\hline $18-29$ years & 80 & 40 \\
\hline 30-39 years & 71 & 36 \\
\hline $40-49$ years & 34 & 17 \\
\hline $50-59$ & 13 & 7 \\
\hline Total & 198 & 100 \\
\hline \multicolumn{3}{|c|}{ Gender } \\
\hline Male & 95 & 48 \\
\hline Female & 103 & 52 \\
\hline Total & 198 & 100 \\
\hline \multicolumn{3}{|c|}{ Occupation } \\
\hline Farming & 34 & 15 \\
\hline Fishing & 4 & 2 \\
\hline Trading & 55 & 28 \\
\hline Civil Servants & 68 & 34.3 \\
\hline Commercial Drivers & 40 & 20.7 \\
\hline Total & 198 & 100 \\
\hline \multicolumn{3}{|c|}{ Level of education attained } \\
\hline Primary & 29 & 14.6 \\
\hline Secondary & 102 & 55.5 \\
\hline Tertiary & 52 & 26.3 \\
\hline None & 15 & 7.6 \\
\hline Total & 198 & 100 \\
\hline \multicolumn{3}{|c|}{ Family Size } \\
\hline $1-5$ years & 99 & 50 \\
\hline 6-10 years & 70 & 36 \\
\hline $11-15$ years & 6 & 3 \\
\hline 16-38 years & 1 & 1 \\
\hline Undetermined & 22 & 10 \\
\hline
\end{tabular}

Raimi Morufu Olalekan, et al. The Sources of Water Supply, Sanitation Facilities and Hygiene Practices Copyright(C Raimi Morufu Olalekan, et al. in an Island Community: Amassoma, Bayelsa State, Nigeria. Public H Open Acc 2019, 3(1): 000134. 


\begin{tabular}{|c|c|c|}
\hline Total & $\mathbf{1 9 8}$ & $\mathbf{1 0 0}$ \\
\hline \multicolumn{3}{|c|}{ Duration at Residence } \\
\hline 0-10 years & 125 & 63 \\
\hline 11-20 years & 19 & 10 \\
\hline 21-30 Years & 7 & 4 \\
\hline 31-40 years & 3 & 2 \\
\hline Unknown & 44 & 22 \\
\hline Total & $\mathbf{1 9 8}$ & $\mathbf{1 0 0}$ \\
\hline \multicolumn{3}{|c|}{ 0wnership } \\
\hline Rented & 96 & 48 \\
\hline Landlord/Owner & 102 & 52 \\
\hline Total & $\mathbf{1 9 8}$ & $\mathbf{1 0 0}$ \\
\hline
\end{tabular}

Table 1: Socio-demographic data of respondent.

\section{Water Sources}

Table 2 shows that on the aspect of drinking water $123(62.1 \%)$ use borehole, 112(56.6\%) use sachet water, $64(32.3 \%)$ use rain water, 53(26.8\%) use river/stream, $43(21.7 \%)$ table water and $10(5.0 \%)$ pipe borne. It will suffice to say that most of the respondents depend on borehole water for drinking mainly because it is of good quality.

For cooking, 150(75.8\%) use borehole, $80(40.4 \%)$ rain water, $63(31.8 \%)$ use river/stream, $11(5.5 \%)$ pipe borne and $5(2.5 \%)$ sachet water. It is clear to say that most of the respondents depend on borehole water for drinking, but high number of respondents utilize both borehole and rain water for cooking. This can be attributed to the fact that cooking is already a form of treatment for rain water leading to high use for cooking, For bathing, 135(68.2\%) use water from borehole,
91(45.9\%) use water from the River, 86(43.4\%) use rain water and $10(5.1 \%)$ use pipe borne water. This show that borehole water is by far the most utilized, due to the fact that the other sources, apart from pipe borne, table water will need treatment to prevent skin diseases.

For washing, 127(64.1\%) of the respondents use borehole water, $101(51.0 \%)$ use river/stream, $90(45.5 \%)$ rain water and $9(4.5 \%)$ use pipe borne water. This simply shows that most of the in dwellers in this community depend mostly on borehole as a source of water even for domestic use mainly because it is of good quality, followed by rain water which is not bought but only available during the rainy season. River/stream is followed in line even though it is readily available, but of its quality is poor. Pipe borne water is least, although it is of good quality it is not readily available since it is poorly managed by the state government.

\begin{tabular}{|c|c|c|c|c|c|c|}
\hline Uses/Sources & Borehole & River/stream & Rain & Pipe Borne & Sachet Water & Table Water \\
\hline Drinking & 123 & 53 & 64 & 10 & 112 & 43 \\
\hline Cooking & 150 & 63 & 80 & 11 & 5 & 0 \\
\hline Bathing & 135 & 91 & 86 & 10 & 0 & 0 \\
\hline Washing & 127 & 101 & 90 & 9 & 0 & 0 \\
\hline Total & $\mathbf{5 3 5}$ & $\mathbf{3 0 8}$ & $\mathbf{3 2 0}$ & $\mathbf{4 0}$ & $\mathbf{1 1 7}$ & $\mathbf{4 3}$ \\
\hline
\end{tabular}

Table 2: Sources of water.

*some respondents had multiple answers.

Table 3 shows that of the 198 respondents about $119(60.1 \%)$ had their different perceptions about the quality of water being consumed from the different sources.
About 97(48.9\%) made complains about the colour, $58(29.3 \%)$ said it has taste, $72(36.4 \%)$ said it contains particles, 50(25.3\%) complained about its odour, while about $79(39.9 \%)$ had no complains about their water which is from borehole or pipe borne water. 


\begin{tabular}{|c|c|c|}
\hline Perceptions & Frequency (f) & Percentage (\%) \\
\hline Colour & 97 & 48.9 \\
\hline Taste & 58 & 29.3 \\
\hline Particles & 72 & 36.4 \\
\hline Odour & 50 & 25.3 \\
\hline None & 79 & 39.9 \\
\hline Total & $\mathbf{3 5 6}$ & \\
\hline
\end{tabular}

Table 3: Perceptions of the people on the water used.

*some respondents had multiple answers.

Figure 2 below shows that water is mostly stored in plastics buckets $153(77.3 \%)$, about $14(7.0 \%)$ use storage tanks and about $31(15.7 \%)$ of respondents store their water in plastic drums.

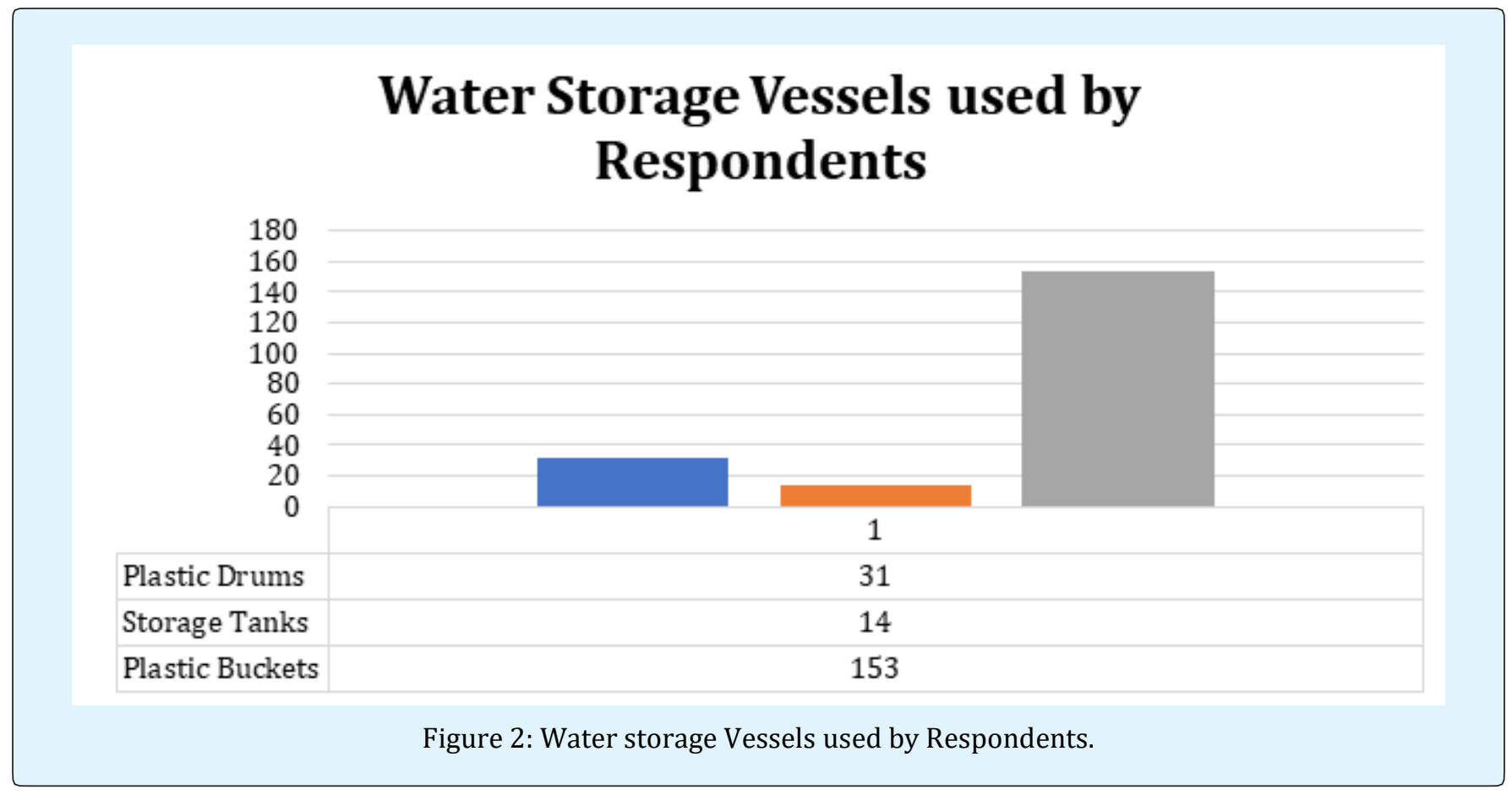

Table 4 shows that about $133(67.2 \%)$ of respondents get their water through the tap, $43(21.7 \%)$ fetch directly from the rain, while $22(11.1 \%)$ scoop water from the river.

\begin{tabular}{|c|c|c|}
\hline Perception & Frequency (f) & Perception (\%) \\
\hline Scoop from River & 22 & 11.1 \\
\hline Collection from Rain & 43 & 21 \\
\hline Taps & 133 & 67.9 \\
\hline Total & 198 & \\
\hline
\end{tabular}

Table 4: Methods of withdrawal of water from various source.

Figure 3 shows the rate at which Storage containers are cleaned at varying intervals, about $53(26.8 \%)$ clean their storage containers one weekly, 41(20.7\%) clean theirs twice weekly, $17(8.6 \%)$ clean three times weekly,
18(9.1\%) five times weekly, 23(11.2\%) clean their containers occasionally and $36(18.2 \%)$ on demand and $2(1.0 \%)$. 


\section{Frequency at which Storage Containers are Cleaned}

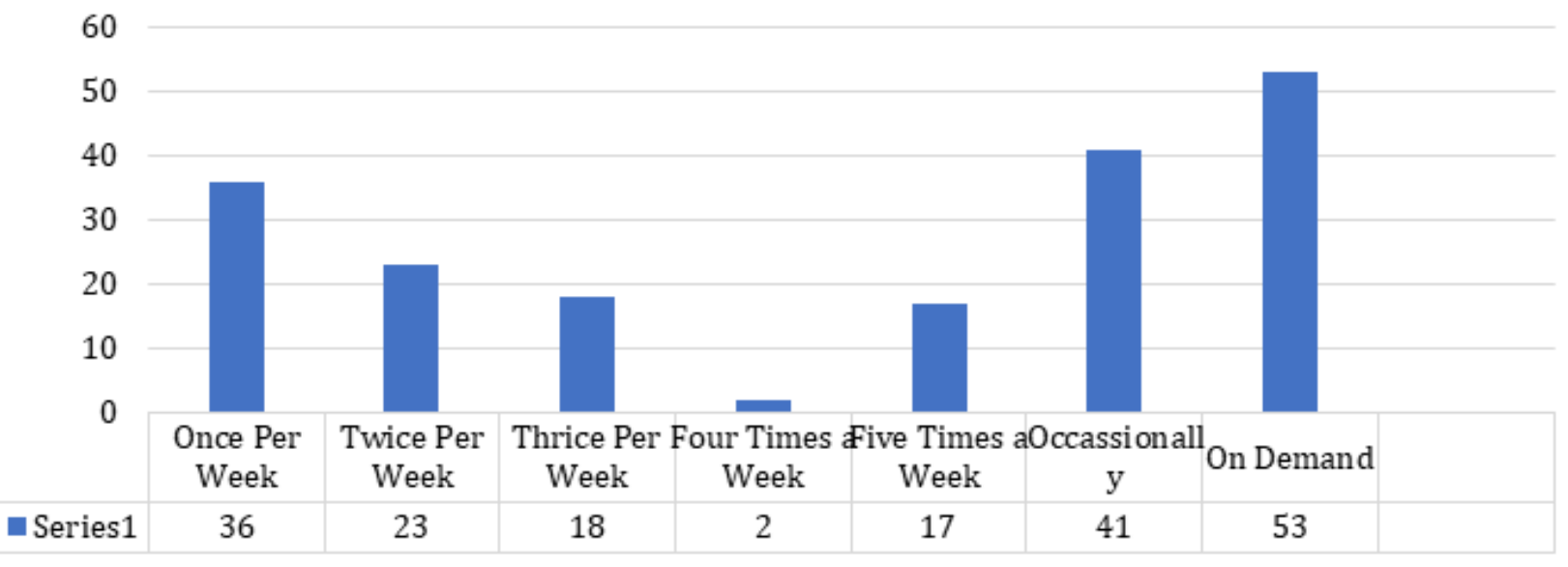

Figure 3: Frequency at which storage containers are cleaned.

Table 5 shows that $136(68.7 \%)$ respondents do no form of treatment to the water used. This can be attributed to the fact that most of these respondents source their water from boreholes that are already treated. However, it can be noted that $30(15.2 \%)$ treat their water by storing them for a period of time in containers, $20(10.1 \%)$ use water guard, while $12(6.0 \%)$ boil their water or a combination of both.

\begin{tabular}{|c|c|c|}
\hline Treatment Methods & Frequency & Percentage (\%) \\
\hline Storage & 30 & 15.2 \\
\hline Water guard & 20 & 10.1 \\
\hline Boiling & 12 & 6 \\
\hline None & 136 & 68.7 \\
\hline Total & $\mathbf{1 9 8}$ & \\
\hline
\end{tabular}

Table 5: Water treatment methods used by respondents.

Table 6: gives a breakdown of the amount used by the families of the respondents per day. $88(44.4 \%)$ use a total of 0 -100litres, $49(24.8 \%)$ could not quantify the amount used by their families, 42(21.2\%) use 101-200litres, $11(5.6 \%)$ use between 201-300litres, 5(2.5\%) use 301400litres, about 3(1.5\%) use 401-500litres daily while $49(24.8 \%)$ of the respondents could not quantify the amount of water used daily. The high usage of water can be attributed to the flush type toilet facility that utilizes more water.

\begin{tabular}{|c|c|c|}
\hline Quantity (Liters) & Frequency & Percentage (\%) \\
\hline $0-100$ & 88 & 44.4 \\
\hline $101-200$ & 42 & 21.2 \\
\hline $201-300$ & 11 & 5.6 \\
\hline $301-400$ & 5 & 2.5 \\
\hline $401-500$ & 3 & 1.5 \\
\hline Unquantifiable & 49 & 24.8 \\
\hline Total & 198 & \\
\hline
\end{tabular}

Table 6: Quantity of water used per day.

\section{Sanitation}

Table 7 shows the different toilet facilities used by the community. 81(40.9\%) use septic tank, 67(33.8\%) defecate in the open, $31(15.7 \%)$ defecate into the river, $26(13.1 \%)$ use the traditional pit latrines, while $18(9.0 \%)$ use ventilated improve pit latrines

\begin{tabular}{|c|c|c|}
\hline Facilities & Frequency & Percentage (\%) \\
\hline Septic tank & 81 & 40.9 \\
\hline Open defecation & 67 & 33.8 \\
\hline River & 31 & 15.7 \\
\hline Traditional Pit Latrine & 26 & 13.1 \\
\hline $\begin{array}{c}\text { Ventilated improve Pit } \\
\text { Latrine }\end{array}$ & 18 & 1.5 \\
\hline Total & $\mathbf{2 2 3}$ & 9 \\
\hline
\end{tabular}

Table 7: Toilet facilities

*Some Respondents had multiple answers. 
Table 8 shows that of the 198 respondents, 108(54.5\%) perceive their toilet facilities to be clean, $57(28.8 \%)$ dirty, $11(5.6 \%)$ perceive theirs to be fair, while 22 of the respondents where undetermined. Also, 123(62.1\%) have their baths in closed bathrooms, 78(39.4\%) bath in the river, while $31(15.7 \%)$ use open type bathrooms.

\begin{tabular}{|c|c|c|}
\hline $\begin{array}{c}\text { Respondents Perception } \\
\text { of Facilities }\end{array}$ & Frequency & $\begin{array}{c}\text { Percentage } \\
\text { (\%) }\end{array}$ \\
\hline Clean & 108 & 54.5 \\
\hline Dirty & 57 & 28.8 \\
\hline Undetermined & 11 & 5.6 \\
\hline Total & $\mathbf{1 9 8}$ & \\
\hline
\end{tabular}

Table 8: Sanitary condition of toilet.

Table 9 shows that about $126(63.6 \%)$ respondents dispose refuse in open dump sites, 44(22.2\%) bury their wastes, 21(10.6\%) burn theirs while 19(9.9\%) dump waste in the river. 121(61.1\%) of the respondents dispose waste water by soaking it into soil, $54(27.3 \%)$ in open drainage, $19(9.9 \%)$ dispose waste water in the river, while $10(5.1 \%)$ dispose waste water anywhere around the environment.

\begin{tabular}{|c|c|c|c|}
\hline & & Frequency (f) & $\begin{array}{c}\text { Percentage } \\
\text { (\%) }\end{array}$ \\
\hline Site & Rivers & 19 & 9.9 \\
\hline & Burning & 21 & 10.6 \\
\hline & Open dump site & 126 & 63.6 \\
\hline & Burying & 44 & 22.2 \\
\hline & \multicolumn{4}{|c|}{ Total } & 210 & \\
\hline Wite & \multicolumn{4}{|c|}{ River } & 19 & 9.9 \\
\hline & Open Drainage & 54 & 27.3 \\
\hline & $\begin{array}{c}\text { Soak into soil } \\
\text { backyard }\end{array}$ & 121 & 61.1 \\
\hline & $\begin{array}{c}\text { Around the } \\
\text { environment }\end{array}$ & 10 & 5.1 \\
\hline & Total & $\mathbf{2 0 4}$ & \\
\hline \hline
\end{tabular}

Table 9: Methods of waste disposal.

*Some Respondents had multiple answers

\section{Hygiene Practices}

Table 10 shows that about 190(95.9\%) imbibe hand washing practices immediately after toilet visit, 152(76.8\%) before cooking, 144(72.7\%) after cooking, while $170(85.9 \%)$ wash their hands before cooking. In addition, $99(50.0 \%)$ of the respondents cook inside their homes, 43(21.7\%) outside their homes, 30(15.2\%) cook in open places, while $29(14.6 \%)$ cook in a closed place not attached to their homes.

\begin{tabular}{|c|c|c|c|}
\hline & & $\begin{array}{l}\text { Frequency } \\
\text { (f) }\end{array}$ & $\begin{array}{c}\text { Percentage } \\
(\%)\end{array}$ \\
\hline \multicolumn{4}{|c|}{ Hand Washing } \\
\hline \multirow[t]{5}{*}{ Practices } & After toilet visit & 190 & 95.9 \\
\hline & Before cooking & 152 & 76.8 \\
\hline & After cooking & 144 & 76.7 \\
\hline & Before cooking & 170 & 85.9 \\
\hline & Total & 656 & \\
\hline \multicolumn{4}{|c|}{ Cooking Place } \\
\hline \multirow[t]{5}{*}{ Site } & Closed & 29 & 14.6 \\
\hline & Opened & 30 & 15.2 \\
\hline & Outside home & 43 & 21.7 \\
\hline & Inside home & 99 & 50 \\
\hline & Total & 201 & \\
\hline
\end{tabular}

Table 10: Personal hygiene.

*Some respondents had multiple answers

\section{Health Impacts}

Table 2.11 shows that $50(25.3 \%)$ of the respondents complained of malaria, 41(20.7\%) complained of diarrhoea, 18(9.1\%) skin rash, 4(2.0\%) complained of cough, while $102(51.5 \%)$ of the respondents had no health complains.

\begin{tabular}{|c|c|c|}
\hline Disease & Frequency (f) & Percentage (\%) \\
\hline None & 102 & 51.5 \\
\hline Malaria & 50 & 25.3 \\
\hline Skin rash & 18 & 9.1 \\
\hline Diarrhoea & 41 & 20.7 \\
\hline Cough & 4 & 2 \\
\hline Total & $\mathbf{2 1 5}$ & \\
\hline
\end{tabular}

Table 11: Common health problems.

*Some respondents had multiple answers

About $63(31.8 \%)$ of them attributed poor sanitation as a causal factor, $46(23.3 \%)$ of the respondents associated water as a possible causal factor, while 89(44.9\%) did not attribute their health challenges to any causal factor. 103(52.0\%) purchase drugs from patent drug stores for treatment, 73(36.9\%) visit hospitals, while 22(11.1\%) patronize traditional doctors.

\section{Discussion}

This study establishes that the sources of water supply in the Island town of Amassoma Community are Borehole, Pipe borne, River, rain, Table water and Sachet water, with borehole water being the commonest source of water for different activities in the community and are 
amongst those listed by Ordinioha that communities depend on; indicating that access to water is not the problem as majority of residents in the community use at least 61 litres of water per capita per day. This is lower than the 120 litres recommended by the national water supply and sanitation policy but higher than the 20 litres defined by WHO and UNICEF as reasonable access $[11,12]$.

The perception of the quality of water available varied. The water supplied to the people was either coloured, odorous, had particles or had taste. $39.9 \%$ of respondents had none of such perceptions. This variability could be due to the subjectivity of the respondents' perception of the water quality.

There is however problem with the quality of some of the sources of water which is indicated by the presence of colour, particles, odour and taste as perceived by respondents, since water of satisfactory quality should in addition to its chemical and microbiological qualities be colourless, odourless and tasteless $[3,4,5,6]$. The poor quality of a few of this water sources may be due to the presence of high sodium (due to saline intrusion from the sea), iron and manganese in boreholes drilled in some communities in the Niger delta as proposed by Ordinioha, Morufu and Clinton. The presence of poor water quality as perceived by a few residents in the community would have also necessitated the fewer percentage of water treatment amongst them, as compared to the $68.7 \%$ that do not use any form of treatment who, on the other hand, have good water quality (37.9\%). This is similar to the work done by Miner, et al. In a community in Plateau state which showed that $54 \%$ of respondents practiced at least one method of purification in their household, the commonest of which was the addition of water guard $(10.1 \%)$, while the commonest treatment option in this study is storage $(15.2 \%)$ and is probably due to fewer percentage of water with particles. However, the treatment options of boiling, water guard and storage are similar to those described by Ordinioha. The study showed that all residents wash their water storage container on demand (53\%), occasionally (41\%), once a week (36\%) or two-weekly (23\%).

From this study, about $65.6 \%$ of the study population use less than 30litres of water per capita per day (Considering the amount used daily by the family and the average family size of seven). This falls short of the recommendation by the National water supply and sanitation policy of the delivery of 30litres per capita/day of water for rural areas. A possible reason for this shortfall could be due to inadequate funds to purchase the needed quantity of water since even the said borehole water is sold. This is in accordance with a study done by
Nwankwoala where it was stated that rural water supply suffered from inadequate funding amongst many other problems [13]. This inadequate quantity of water available to these individuals makes hygiene and good sanitation difficult and almost impossible. This may eventually lead to ill health or infections as established in the study done in 2012 by Chitingwiza [14]. The Toilet facilities established by this study in Amassoma include septic tank, Traditional pit latrine, ventilated improved pit latrine, the river and open spaces which include bushes and paths. Septic tank is the commonest (40.9\%) while the ventilated improved pit latrine is the least common (1.5\%). 33.8\% of the respondents defecate in the open. This is greater than previous study by WHO which estimated that $22 \%$ of the Nigerian populace defecate in the open [15]. It could also be due to the factors established earlier by Nwankwoala [13] or due to the ignorance of the people about the effects of such practice. This could also explain the use of the river as a toilet facility. A large population of the study (76.3\%) could not specify how their toilets are emptied when the get filled. This may also account for the usage the river and open places. The bathroom facilities followed closely with that of the toilet facilities with about $62.1 \%$ having bathrooms in their homes, $39.4 \%$ using the river while $15.7 \%$ use open bathrooms.

Disposal of solid waste followed the common trend in Nigeria where a study noted that dumping of solid waste is a common practice in Nigeria [16]. 63.6\% of respondents dump their waste in the open. Dumping of refuse in the river is not very common (9.9\%), which may be due to the fear of filling the river with refuse. Waste water followed closely with $61.1 \%$ soaking theirs in the soil behind their homes while only $5.1 \%$ reported to disposing their waste water just anywhere. Consequently, adequate hygiene knowledge and practice is very crucial as it may not be possible to prevent diseases by just the provision of adequate water and good sanitation facilities. Therefore, assessment of hygiene practices in the community was necessary. This is in accordance with the study carried out in 2010 by UNICEF $[15,6]$.

Hand washing is an important contributor to adequate hygiene and UNICEF collaborated this by stating that by adopting hand washing with soap at critical times, families can reduce the occurrence of diarrhoea diseases in children by as much as $44 \%[15,5,6]$. From the study, practice of hand washing at certain critical times (after toilet visits, before cooking, after cooking and before eating) were considered and it is noticed that hand washing is common practice amongst the people. This probably explains why diarrhoea diseases $(20.7 \%)$ are not common as malaria $(25.3 \%)$ in the community. A 
previous study referred to malaria as the single most important cause of death in the country and it is due to inadequate drainage of waste water [17,4]. Diarrhoea $(20.7 \%)$ may be due to poor water supply since it is one of the water-related diseases suffered by villagers and this is in agreement with the study done in 2002 by Uzomah, Scholz $[18,4-6]$.

The water sources, the type and state of sanitation facilities and the hygiene practices also had a financial implication on the individuals in the community [19-31]. Depending on their orientation, education and financial state of the family, some patronize patent drug stores, some traditional doctors while a few visit hospitals for health services. They also have to spend money which would have been used to settle other necessities in their family or households [32-47].

\section{Conclusion}

Life depends on clean and healthy environment. However, low environmental standards lead to reduced life expectancy. Water borne diseases have been associated with air, water pollution, sanitation, personal hygiene and waste disposal etc. Other diseases such as malaria, cholera, typhoid and ebola are caused through exposure to harmful environment. Interestingly, sources of water, sanitation facilities and hygiene practices are interrelated issues. Adequate water supply, good sanitation facilities and proper hygiene practices improve the lives of the people. Inadequate water supply and poor sanitation facilities in Amassoma community predispose the people to water related diseases. A good practice of hygienic behaviour was established in the study population but hygiene in the absence of adequate water supply and sanitation facilities cannot prevent diseases. As the town is increasingly becoming prominent in terms of educational and commercial activities, there is need to address the challenges through improved basic amenities along with prevention of environmental degradation in line with national regulations for sustainable development. Furthermore, there is to build community support through public education and awareness, enhance public private partnerships in environmental management and ensure coordinated engagement with all community stakeholders in order to achieve an integrated and holistic implementation of the WASH policy.

\section{Recommendations}

This study identified some gaps in the availability of adequate water supply and sanitation facilities in Amassoma community, hence the following recommendations.
- The Local and State governments should ensure that well treated pipe-borne water is provided to all areas of Amassoma Community. This should be selfsustaining so as to allow for adequate water supply.

- Public Toilet facilities should be constructed and maintained in the community by the Community Development Committee. A law preventing the use of the river and bushes as toilet should be promulgated by the Chief-in-council and effectively enforced.

- State institutions should be strengthened and emphases on citizen advocacy should be encouraged.

- Health Education programmes and campaigns should be conducted on the need to keep a healthy environment, its benefit to the community and proper development of individuals in the community. This could be conducted by the Ministries of Health and Environment with active participation of the members of the Community, in the spirit of self-reliance.

- A further study on the effect of inadequate water supply, poor sanitation facilities and hygiene on the individuals in Amassoma Community should be carried out.

\section{References}

1. Esrey SA, Potash JB, Roberts L, Shiff C (1991) Effects of improved water supply and sanitation on ascariasis, diarrhoea, dracunculiasis, hookworm infection, schistosomiasis, and trachoma. Bull World Health Organ 69(5): 609-621.

2. Merchant AT, Jones C, Kiure A, Kupka R, Fitzmaurice G, et al. (2003) Water and sanitation associated with improved child growth. Eur J Clin Nutr 57(12): 15621568.

3. Morufu Raimi, Clinton Ezekwe (2017) Assessment of Trace Elements in Surface and Ground Water Quality. Lambert Academic Publishing.

4. Raimi MO, Sabinus CE (2017) An Assessment of Trace Elements in Surface and Ground Water Quality in the Ebocha-Obrikom Oil and Gas Producing Area of Rivers State, Nigeria. International Journal for Scientific and Engineering Research 8(6).

5. Raimi MO, Omidiji AO, Abdulraheem AF, Ochayi EO (2018) A Survey of Hand Washing Behavior and Awareness among Health Care Workers in Health Care Facilities in Kubwa District of Bwari Area Council, F.C.T. Abuja, Nigeria. Annals of Ecology and Environmental Science 2(2): 1-18. 
6. Olalekan RM, Vivien OT, Adedoyin O, Odipe OE, Owobi OE (2018) The sources of water supply, sanitation facilities and hygiene practices in oil producing communities in central senatorial district of Bayelsa state, Nigeria. MOJ Public Health 7(6): 337-345.

7. Aregbeyen JBO (1992) Health Care Utilization in Nigerian Rural Communities. A Focus on Otuo Community and Environs in Edo State. NISER 3: 1-51.

8. Raimi MO, Pigha TK, Ochayi EO (2017) Water-Related Problems and Health Conditions in the Oil Producing Communities in Central Senatorial District of Bayelsa State. Imperial Journal of Interdisciplinary Research 3(6): 1-30.

9. Premoboere Edna Ateboh, Raimi Morufu Olalekan (2018) Corporate Civil Liability and Compensation Regime for Environmental Pollution in the Niger Delta. International Journal of Recent Advances in Multidisciplinary Research 5(6): 3870-3893.

10. www.tiptopglobe.com/city

11. Oloruntoba EO, Agbede OA, Sridhar MKC (2006) Seasonal variation in physicochemical quality of household drinking water in Ibadan, Nigeria, ASSETAn International Journal. 5(1): 70-81.

12. Oloruntoba EO, Agbede OA, Sridhar MKC (2006) Seasonal variation in physico-chemical quality of household drinking water in Ibadan, Nigeria. African Journal of Medicine and Medical Sciences 34: 154165.

13. Nwankwoala HO (2009) Sustainable groundwater development and management in Nigeria; Mission achievable or Mission impossible? Water Resource J 19: 63-68.

14. Zimbabwe C (2012) Factors leading to poor water, sanitation, hygiene among primary school going children. Journal of Pub Health in Africa.

15. WHO/UNICEF (2011) Joint monitoring programme for water supply and sanitation, 2010 estimates for water and sanitation.

16. Babayemi JO, Dauda K T (2009) Evaluation of Solid waste generation, categories and disposal option in developing countries; a case study of Nigeria. Journal of applied sciences and environmental management 13(3): 83-88.
17. Salaam O, Titi (2007) Nigeria - Women's burdens demand socialist action. Democratic Socialist Movement (CWI, Nigeria).

18. Uzomah VC, Scholz M (2007) Water-availability assessment and corresponding public health implications for a rural area in Nigeria. Journal of the Chartered Institution of Water and Environmental Management 16(4): 296-299.

19. Ademiluyi IA, Odugbesan JA (2008) Sustainability and impact of community water supply and sanitation programmes in Nigeria; an overview. African Journal of Agricultural Research 3(12): 811-817.

20. UNAIDS (1997) Report in the Global Joint. United Nations Programme on HIV/AIDS.

21. Akpabio EM (2012) Water supply and sanitation services sector in Nigeria, the policy and practice constraints, pp: 1-24.

22. Bryan GW, Langston WJ (1992) Bioavailability accumulation and effects of heavy metals in sediments with special reference to the United Kingdom estuaries: A review. Environ Pollut 76(2): 89-131.

23. Cairncross S, Feachem R (1999) Environmental Health Engineering in the Tropics, (2 ${ }^{\text {nd }}$ Edn), Wiley and Sons Ltd., Chichester, England.

24. C-GIDD (Canback Global health distribution database) (2008) Canback Dargel.

25. Ezeji JI (2002) Water and sanitation in Nigeria: An input to the United Nation's Commission on Sustainable Development (CSD 12); pp: 1-12.

26. Evans B (2005) Securing Sanitation: the compelling Case to address the Crises. Report produced by the Stockholm International Water institute (SIWI) in collaboration by the World Health Organization (WHO).

27. Fatoki OS, Lujizan O, Ogunfowokan AO (2002) Trace metal pollution in Umata River. Water SA 28(2): 183189.

28. Adeoye GO (2001) Water supply, Environmental Hygiene and Health of University of Lagos, Nigeria. Prepared for the 28th International Faith and Learning Seordioar held at Babcock University, Ilishan-Remo, Ogun State, Nigeria. 
29. Lagos Water Corporation (2012) Organization History.

30. Lagos State Water Corporation (2012) "Welcome to the official website of the LSWC.

31. Lankinen KS, Bergstrom S, Makela PH, Peltomaa M (1994) Health and disease in developing countries. London. The Macmillan Press Limited, pp: 67-78.

32. Matthew Gandy (2006) Water, sanitation and the modern city: Colonial and Post-colonial experiences in Lagos and Mumbai. Human Development Report Office Occasional Paper.

33. Nigeria Biodiversity and Tropical Forestry Assessment (2008), USAID, June 2008, pp: 76.

34. Nwadinigwe CA, Nwaorgu ON (1999) Metal contaminants in some Nigerian well - Head crudes: Comparative Analysis. J Chem Soc Nigeria 24: 118121.

35. Oloruntoba EO, Sridhar MKC (2007) Bacteriological quality of Drinking water from source to household in Ibadan, Nigeria. Afr J Med Med Sci 36(2): 169-175.

36. Onyekakeyah Luke (2006) Water: New realities and challenges, The Guardian, Nigeria, March 2006; 21, pp: 1.
37. Robert VK, Daryle WM (1970) Determining sample size for research activities. Educational and psychological measurement 30(3): 607-610.

38. USAID (2007): Nigeria Water and Sanitation Profile, Ca.

39. Valerie C, Bernadette K (1998) Hygienic, Happy and Healthy A Set of 4 hygiene promotion manuals. London School of Hygiene and Tropical Medicine.

40. Wagner EG, Lanoix JN (1958) Excreta Disposal for Rural Areas and Small Communities. Monogr Ser World Health Organ 39: 1-182.

41. Water Initiative Nigeria (2011) Water sanitation, health and hygiene education in local communities in Ibadan South- west Nigeria, March.

42. World Bank (1993) World Development Report, Washington.

43. www.who.int/topics/sanitation.

44. www.data.worldbank.org/country/nigeria.

45. www.maps-streetview.com/nigeria/amassoma.

46. www.un.org/melliniumgoals/.

47. www.who.int/topics/sanitation. 